Klinička psihologija 10 (2017), 1-2, 23-34

Izvorni znanstveni rad - UDK 159.913

DOI: $10.21465 / 2017-K P-1-2-0002$

\title{
AUTHENTICITY AS A PREDICTOR OF MENTAL HEALTH
}

\author{
Djurdja Grijak \\ University of Novi Sad, \\ Technical faculty "Mihajlo Pupin" Zrenjanin \\ Djure Djakovića bb, 23000 Zrenjanin \\ gdjurdja@gmail.com
}

\begin{abstract}
The aim of this research was to evaluate the relationship between authenticity and mental health on a sample of 706 students. Results showed that all subscales of the Authenticity scale (authentic living, accepting external influence and self-alienation) were correlated with all general scales and subscales of the MHI-38 (psychological distress - anxiety, depression, loss of behavioural/emotional control; psychological well-being - overall positive affect, emotional ties and satisfaction with life and overall mental health index). Hierarchical regression showed that authenticity composed of all three dimensions together is a statistically significant predictor of psychological distress, psychological well-being and overall mental health index. The confirmation that authenticity is closely connected to mental health and significantly contributes to it is a good example of how classic perspectives in psychological counselling can set further directions of research within personality psychology.
\end{abstract}

Key words: authenticity, mental health, students

\section{INTRODUCTION}

Human strengths and virtues, mental health and well-being have long been neglected as a subject of psychological research which dealt with symptoms and disorders (Seligman, 2002). Positive psychologists believe that the reason for this can be found in the fact that the researchers misunderstood the positive aspects of psychological functioning in their attempt to reach a better understanding of people. Only in recent years have psychologists started to focus on positive concepts such as authenticity and mental health.

Carl Rogers, a humanistic psychologist, in trying to understand the human being came to view every individual as a unique being (Schmid, 2004). To be a person, 
according to Rogers, means to live authentically and develop personal potentials in a constructive way. And to live authentically means to be able to keep the balance between the substantial and the relational tasks of living in the process of realizing one's own values and needs, individuality and uniqueness, while at the same time living together with others and meeting the needs and challenges of these relations in interdependence and solidarity. An authentic person is a functional person, claimed Rogers. Therefore, a person who lives authentically is healthy or normal. Within the concept of uniqueness of each person it means that each person is authentic in a different way. According to Rogers, a person's authenticity implies a process, never a state or an end product (Schmid, 2001). Authenticity is a dynamic process whereby one's potentials, characteristics, emotions, values and motivation are discovered and explored, accepted, imbued with meaning or purpose, and actualized (Rogers, 1961).

With the development of positive psychology grew the interest into researching authenticity. In the field of positive psychology, authenticity is defined as owning one's personal experiences, be they thoughts, emotions, needs, preferences, or beliefs, processes captured by the injunction to know oneself and behaving in accordance with the true self (Seligman, 2002). Positive psychologists focused on six overarching human virtues underpinned by 24 character strengths, and represented authenticity together with honesty as character strengths existing within the virtue of courage (Peterson \& Seligman, 2004).

At the same time, numerous attempts were made to define authenticity. These definitions ranged from an individual's ability to understand and own his or her thoughts, emotions, needs, wants, beliefs, and preferences, while behaving consistently with his or her inner thoughts and feelings (Harter, 2002) in accordance between how someone presents himself/herself and what he/she actually is (Snyder \& Lopez, 2009).

Wood, Linley, Maltby, Baliousis and Joseph (2008) relied on the humanistic concept (Barrett-Lennard, 1998) and defined authenticity through self-alienation, accepting external influence and authentic living. People who accept external influence are more prone to self-alienation, and those who accept only certain external influences lead an authentic life. The same authors have constructed an authenticity scale in order to operationalize the tripartite model of authenticity comprising different definitions of authenticity. The factor of self-alienation measures an individual's subjective experience of not knowing oneself and lacking the feeling of integrity. The factor of accepting external influence measures the extent to which an individual believes that they need to adjust their behaviour to the expectations of others. The last factor of authentic living measures the extent of coherence between an individual's behaviour and their values and beliefs. 
In many mainstream counselling psychology perspectives, authenticity is seen as the most fundamental aspect of well-being (Rogers, 1961). These researchers see authenticity not simply as an aspect or precursor to well-being but rather the very essence of well-being and healthy functioning. As such, departures from authenticity are seen as involving increasing psychopathology, i.e. damaging one's mental health. However, many of these approaches have not been subjected to empirical verification, and the empirical evidence that does exist regarding the relationship between authenticity and well-being is mostly indirect and focuses primarily on one or another of the three factors of authenticity.

Numerous philosophical theories have dealt with the positive aspects in life (Deci \& Ryan, 2008; Ryan \& Deci, 2001). Ancient Greek theorists analysed factors of the good life and produced two main theories on well-being which are still central in positive psychology. One of them is hedonism, according to which well-being is the strengthening of positive and weakening of negative feelings. The other one is eudemonism which defines well-being as optimal human functioning and self-realization. Both theories assess well-being based on subjective experience.

According to one model of mental health (Veit \& Ware, 1983), there are two components of mental health - psychological well-being and psychological distress. Well-being is a broad, diverse and diffusive idea, and psychological well-being is defined as a broad construct with numerous cognitive and emotional components such as satisfaction with life, positive and negative emotions, accordance between the expected and actualized life goals. Well-being is defined through three basic components (Myers \& Diener, 1995) - satisfaction with life which measures satisfaction with work and relationships with others, relative existence of positive emotions which measures the existence of pleasant emotions and a positive assessment of the environment, relative absence of negative emotions which implies absence of emotions such as anxiety, depression and anger. Psychological distress describes the negative state of one's mental health. Psychological distress is defined as experiencing lack of interest, sleep problems, feeling of disappointment, sadness, anxiety, desperation and boredom, difficulties in relationships with others (Winefield, Gill, Taylor \& Pilkington, 2012).

In this paper, the author presents a research aimed to evaluate the relationship between dimensions of authenticity - authentic living, accepting external influence and self-alienation and mental health measured through dimensions of psychological distress (Anxiety, Depression, Loss of Behavioural/Emotional Control) and psychological well-being (General Positive Affect, Emotional Ties, Life Satisfaction). Based on previous theoretical and empirical discussions, it is expected that results would show that high authentic living, low acceptance of external influence and low self-alienation (authentic person) is positively correlated with psychological well-being and negatively correlated with psychological distress. 


\section{METHOD}

\section{Participants and procedure}

The study was conducted on 706 students (76.5\% females) from the University in Novi Sad, Business Academy in Novi Sad and State University in Novi Pazar. The average age of participants was 22.58 ( $\mathrm{SD}=5.19$, age span 18-39).

\section{Instruments}

Authenticity. The study used the Authenticity Scale constructed by Wood and associates (Wood et al., 2008) from the humanistic model on tripartite authenticity and psychometrically validated in Serbian by Grijak (2017). The scale consists of three subscales - authentic living (4 items), accepting external influence (4 items) and self-alienation (4 items). Participants were asked to give a subjective assessment of the extent to which each claim on each subscale describes them - from 1 (does not describe me at all) to 7 (describes me very well). The results on each subscale theoretically range from min 4 to max. 28. All subscales are scored so higher scores indicate more of the construct named by the subscale label. The authentic person has high scores on subscale Authentic living and low scores on the other two subscales - Accepting external influence and Self-alienation. The subscale Authentic living questions to what extent a person adjusts their behaviour and emotions to their beliefs, values and actual psychological states. The subscale Accepting external influence shows the participant's belief that they have to conform to the expectations of others. The subscale Self-alienation tests how well the participants know themselves, their values and beliefs. In this research, Authentic living had internal consistency $\alpha=0.68(\mathrm{M}=23.02, \mathrm{SD}=3.99)$, Accepting external influence $\alpha=0.71(\mathrm{M}=11.46, \mathrm{SD}=4.81)$ and Self-alienation $\alpha=0.76(\mathrm{M}=10.75, \mathrm{SD}=$ 5.18). Original subscales Authentic living, Accepting external influence and Selfalienation showed internal consistency as follows: 0.62, 0.67 and 0.79 (Wood et al., 2008), in the Iranian adaptation 0.82, 0.81 and 0.77 (Shamsi et al., 2012), in the French adaptation between 0.77 and 0.82 (Grégoire et al., 2014), and in the Turkish adaptation $0.62,0.67$ and 0.79 (Ilhan \& Özdemir, 2013).

MHI-38 (Mental Health Inventory-38; Veit \& Ware, 1983). MHI-38 includes 38 items divided into six subscales, consisting of two general scales, Psychological distress with 24 items (anxiety -9 items, depression -4 items, loss of behavioural/ emotional control - 9 items) and Psychological well-being with 14 items (overall positive affect - 10 items, emotional ties -2 items and satisfaction with life -1 item). Possible answers included 1 - all of the time, 2 - most of the time, $3-\mathrm{a}$ good bit of the time, 4 - some of the time, 5 - a little of the time, 6 - none of the 
time. The results theoretically range from min. 9 to max 54 on the subscale Anxiety, from min. 4 to max. 23 on the subscale Depression, from min. 9 to max. 53 on the subscale Loss of Behavioural/Emotional Control, from min. 10 to max. 60 on the subscale General Positive Affect, from min. 2 to max. 12 on the subscale Emotional Ties, from min. 1 to max. 6 on the subscale Life Satisfaction. All subscales are scored so higher scores indicate more of the construct named by the subscale label. Thus, higher scores on three subscales indicate positive states of mental health (General Positive Affect, Emotional Ties, Life Satisfaction) and higher scores on the other three subscales indicate negative states of mental health (Anxiety, Depression, Loss of Behavioural/Emotional Control). In general scales, results on the scale Psychological Distress range theoretically from min. 24 to max. 142 and on the scale Psychological Well-being results theoretically range from min 14 to max. 84. Higher scores on Psychological Distress indicate negative states of mind, while higher scores on Psychological Well-being indicate positive states. The overall mental health index covers all the items (results theoretically range from min. 38 to max. 226) and high values imply high psychological well-being and relatively low psychological distress. Also, high values on the general scale Psychological distress imply a negative mental health status. In this research, the general scale Psychological distress had an internal consistency $\alpha=0.81(\mathrm{M}=60.36, \mathrm{SD}=19.23)$, and the subscale Psychological well-being $\alpha=0.75(\mathrm{M}=54.5511, \mathrm{SD}=11.26)$. In previous research the estimates of internal consistency for the Mental Health scales were high - for Psychological Distress items 0.94 and for Psychological Well-being items 0.92 (Heubeck \& Neill, 2000).

\section{RESULTS}

In order to answer the question about the relationship between authenticity and mental health a descriptive statistical analysis was conducted and Pearson correlation coefficients were calculated. As results showed that there were correlations, all variables were included in the hierarchical regression analysis. A series of hierarchical regressions was conducted in which criterion variables were scores on the scales Psychological distress and Psychological well-being and Mental health index, control variables were age and gender (Model 1), and predictive variables were all three subscales on the Authenticity Scale - Authentic living (Model 2), Accepting external influence (Model 3) and Self-alienation (Model 4). Table 1 shows descriptive indicators for all three factors on the Authenticity Scale and all factors on MHI-38.

Results of means on all subscales of the Authentic scale show high scores on the subscale authentic living and moderate scores on Accepting external influence and Self-alienation (results theoretically range from $\min 4$ to $\max 28$ on each subscale). This could indicate that participants as young adults know their motives, emotions and thoughts, but still accept the influence of others and have some feelings of self- 
Table 1. Descriptive statistics

\begin{tabular}{llrrrrr}
\hline & & $N$ & \multicolumn{1}{c}{$M$} & \multicolumn{1}{c}{$S D$} & Min & Max \\
\hline \multirow{2}{*}{ Authenticity } & Authentic living & 706 & 23.02 & 3.99 & 4 & 28 \\
& Accepting external influence & 706 & 11.46 & 4.81 & 4 & 28 \\
& Self-alienation & 706 & 10.75 & 5.18 & 4 & 28 \\
\hline \multirow{4}{*}{ MHI-38 } & Psychological distress & 706 & 60.36 & 19.23 & 24 & 137 \\
& Anxiety & 706 & 22.81 & 7.05 & 8 & 48 \\
& Depression & 706 & 8.81 & 3.47 & 4 & 23 \\
& Loss of behavioural/emotional & 706 & 20.65 & 7.18 & 9 & 48 \\
& control & 706 & 54.55 & 11.26 & 19 & 84 \\
& Psychological well-being & 706 & 38.62 & 8.26 & 15 & 60 \\
& Overall positive affect & 706 & 7.99 & 2.62 & 2 & 12 \\
& Emotional ties & 706 & 4.04 & 1.11 & 1 & 6 \\
& Satisfaction with life & 706 & 109.73 & 23.38 & 58 & 203 \\
\hline
\end{tabular}

Note: $M$ - Mean, $S D$ - Standard deviation.

alienation. According to the theoretical range of all subscales and general scales of MHI-38, results could be interpreted as moderate psychological distress and high psychological well-being of participants.

Values of Pearson correlation coefficients between dimensions of authenticity and dimensions of mental health are significant. Results are shown in Table 2.

The results showed that the Authenticity Scale is in significant correlation with MHI-38 ( $\mathrm{p}<0.01)$. Subscale Authentic living is in significant positive correlation with psychological well-being $(\mathrm{r}=0.21 ; \mathrm{p}<0.01)$ and significant negative correlation with psychological distress $(\mathrm{r}=-0.22 ; \mathrm{p}<0.01)$ and mental health index $(\mathrm{r}$ $=-0.23 ; \mathrm{p}<0.01)$. Subscale Accepting external influence is in significant positive correlation with psychological distress $(\mathrm{r}=-0.35 ; \mathrm{p}<0.01)$ and mental health index $(\mathrm{r}=-0.34 ; \mathrm{p}<0.01)$ and in significant negative correlation with psychological wellbeing ( $r=-0.25 ; \mathrm{p}<0.01$ ). Subscale Self-Alienation is in significant positive correlation with psychological distress $(\mathrm{r}=0.44 ; \mathrm{p}<0.01)$ and mental health index $(\mathrm{r}=$ $0.43 ; \mathrm{p}<0.01)$ and significant negative correlation with psychological well-being $(\mathrm{r}=-0.34 ; \mathrm{p}<0.01)$. Pearson correlation coefficients imply negative correlations of the subscale Authentic living to the subscales of Accepting external influence and Self-alienation $(r=-0.278$ and $r=-0.214)$, and a positive correlation between the second and third subscale $(r=0.652)$. All correlations are significant at the level of $p<0.01$. These results could indicate that scale has two higher-order objects of measurement. The one is Authentic living and the other is consisted of Accepting external influence and Self-alienation. Thus, the subscale Authentic living measures adaptive authenticity and Accepting external influence and the Self-alienation me- 


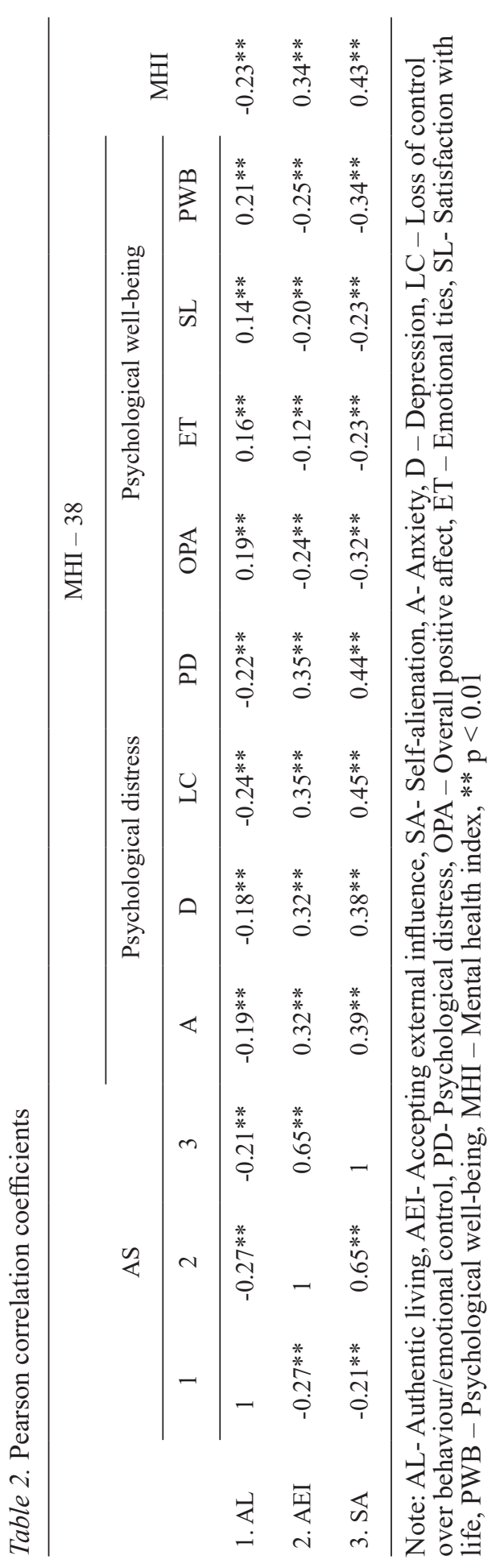

(C) "Naklada Slap", 2017. Sva prava pridržana. 
asures maladaptive authenticity and this was their order in the analyses (Grijak, 2017).

Hierarchical regression analysis was used to check the assumption from previous researches that authenticity is the most fundamental aspect of well-being (Wood et al. 2008). A series of hierarchical regressions was conducted in which criterion variables were scores on the scales Psychological distress and Psychological wellbeing and Mental health index, control variables were age and gender (Model 1), and all three subscales on the Authenticity Scale - Authentic living as adaptive authenticity (Model 2), Accepting external influence as maladaptive authenticity (Model 3) and Self-alienation as maladaptive authenticity (Model 4) were the predictors. The results are shown in Table 3.

The results of hierarchical regression analysis show that authenticity composed of three dimensions (authentic living, accepting external influence and self-alienation) is a moderate predictor of psychological distress, psychological well-being and mental health index (Model 4). Also, results showed that maladaptive authenticity (Model 3 and Model 4 included measures of maladaptive authenticity - accepting external influence and self-alienation) is a better predictor than adaptive authenticity (authentic living in Model 2) according to the explained variance of each.

Betas and semi-partial correlations for the regression analyses are shown in Table 4.

Table 3. Hierarchical regression analysis

\begin{tabular}{ccccccccc}
\hline & & $\mathrm{R}^{2}$ & $\Delta \mathrm{R}^{2}$ & $\mathrm{~F}$ & $\Delta \mathrm{F}$ & $\mathrm{p}$ & $\beta$ & $\mathrm{sr}$ \\
\hline \multirow{3}{*}{ PD } & Model 1 & 0.010 & - & 1.06 & - & 0.349 & - & - \\
& Model 2 & 0.018 & 0.007 & 1.207 & 1.49 & 0.223 & 0.086 & 0.086 \\
& Model 3 & 0.046 & 0.035 & 3.23 & 7.49 & 0.007 & 0.191 & 0.189 \\
& Model 4 & 0.143 & 0.133 & 11.22 & 31.23 & 0.000 & 0.364 & 0.366 \\
\hline \multirow{4}{*}{ PW } & Model 1 & 0.009 & - & 0.894 & - & 0.411 & - & - \\
& Model 2 & 0.018 & 0.009 & 1.21 & 1.84 & 0.177 & 0.095 & 0.095 \\
& Model 3 & 0.022 & 0.013 & 0.894 & 2.69 & 0.102 & 0.116 & 0.115 \\
& Model 4 & 0.112 & 0.103 & 8.51 & 23.53 & 0.000 & 0.322 & 0.323 \\
\hline \multirow{2}{*}{ MH } & Model 1 & 0.004 & - & 0.42 & - & 0.657 & - & - \\
& Model 2 & 0.013 & 0.009 & 0.907 & 1.877 & 0.172 & 0.096 & 0.096 \\
& Model 3 & 0.032 & 0.027 & 2.193 & 5.72 & 0.02 & 0.168 & 0.166 \\
& Model 4 & 0.138 & 0.134 & 10.76 & 31.301 & 0.00 & 0.366 & 0.366 \\
\hline
\end{tabular}

Note: PD - psychological distress; PW - psychological well-being; MH index - Mental health index; Model 1 - age and gender; Model 2 - Authentic living; Model 3 -Accepting external influence; Model 4 - Self-alienation; $\Delta \mathrm{R}^{2}$-change in the percent of the explained variance; $\Delta \mathrm{F}-\mathrm{F}$ test for testing the significance of the change in the percent of the explained variance. 
Table 4. Betas and semi-partial correlations between authenticity factors and outcome variables in full hierarchical regression model (Model 2, Model 3, Model 4)

\begin{tabular}{llll}
\hline & & \multicolumn{1}{c}{$\beta$} & sr \\
\hline \multirow{2}{*}{ PD } & Model 2 & 0.086 & 0.086 \\
& Model 3 & $0.191^{*}$ & 0.189 \\
& Model 4 & $0.364^{* *}$ & 0.366 \\
\hline \multirow{2}{*}{ PW } & Model 2 & 0.095 & 0.095 \\
& Model 3 & 0.116 & 0.115 \\
& Model 4 & $0.322^{* *}$ & 0.323 \\
MH & Model 2 & 0.096 & 0.096 \\
index & Model 3 & $0.168^{*}$ & 0.166 \\
& Model 4 & $0.366^{* *}$ & 0.366 \\
\hline
\end{tabular}

Model 2, Model 3 and Model 4 variables (see Table 3).

$* \beta$ significant at $\mathrm{p}<0.05$.

$* * \beta$ significant at $\mathrm{p}<0.01$.

Results confirm the value of authenticity as a composite of three dimensions in the prediction of psychological distress, psychological well-being and mental health index (Model 4).

\section{DISCUSSION}

This research aimed to evaluate the relationship between dimensions of authenticity - authentic living, accepting external influence and self-alienation and mental health measured through dimensions of psychological distress (Anxiety, Depression, Loss of Behavioural/Emotional Control) and psychology well-being (General Positive Affect, Emotional Ties, Life Satisfaction) on a sample of students (N = 706). Based on previous theoretical and empirical discussions, it is expected that results would show that high authentic living, low acceptance of external influence and low self-alienation (authentic person) is positively correlated with psychological well-being and negatively correlated with psychological distress (high psychological well-being and low psychological distress characterize a mentally healthy person). Overall results confirmed these expectations and confirmed that authenticity is closely connected to mental health.

Correlations between the Authenticity Scale and MHI-38 are in accordance with the theoretical expectations (Wood et al., 2008). All subscales of the Authenticity Scale are in correlation with psychological distress, psychological well-being and mental health index (mental health index value indicates high scores on one general scale and low scores on the other general scale - i.e., high value of MHI shows 
high scores on the scale of psychological well-being, and low scores on the scale of psychological distress). Authentic living as an aspect of authenticity is defined as coordination between perceived experience and behaviour, i.e. coordination of behaviour and expressing emotions with actual psychological states, beliefs and thoughts. Results show that overall positive affect, emotional ties and satisfaction with life positively correlate with honesty to oneself and living in accordance with one's values and beliefs (authentic living). Also, with higher sorrow, disappointment, despair, anxiety, difficulties in relationships with others and lack of interest is expected lower authentic living. Accepting external influence has a positive correlation with psychological distress and mental health index and a negative correlation with psychological well-being. This aspect of authenticity involves the belief that one needs to conform to the expectations of others, and a reason for this result may be found in the fact that the participants were young people who, developmentally speaking, are more authentic when their self is being accepted by other people (Harter et al., 1996; Neff \& Harter, 2002). Self-alienation has a significant positive correlation with psychological distress and mental health index and a significant negative correlation with psychological well-being. The results are as expected, given that this aspect of authenticity, self-alienation, is defined as a mismatch between the conscious awareness (experience represented in the cognitive sphere) and actual experience (the true self, including actual psychological states, emotions and beliefs).

The results of hierarchical regression analysis confirmed the values of the correlations and showed that authenticity composed of three dimensions - authentic living, accepting external influence and self-alienation explain $14.3 \%$ of psychological distress, $11.2 \%$ of psychological well-being and $13.8 \%$ of mental health index. We can also very cautiously conclude from the results of hierarchical regression analysis that authentic living, as adaptive authenticity had no predictive power of mental health (included in Model 2), but dimensions of maladaptive authenticity Accepting external influence (included in Model 2) and Self-alienation (included in Model 4) were statistically significant predictors of psychological distress and mental health index. Finally, we can conclude that authenticity is only one of the positive predictors of mental health.

Limitations of this research might relate to the sample of participants. Size of the sample $(\mathrm{N}=706)$ might have caused variations in results and also influenced the final result on the predictive value of authenticity. Further, regarding the gender structure of the sample, there were $76.5 \%$ females and this could have influenced the overall results.

Suggestions for further researches relate to the sample (size and gender structure), whereby it would be significant to evaluate the same relation between authenticity and mental health in early age and in middle and older age groups. It would also be significant to evaluate the connection of additional variables with mental health. As the results showed that authenticity explains only $11-14 \%$ of variance of mental health, further research should include other variables as other 
personality traits into analysing what else, together with authenticity, predicts mental health.

\section{CONCLUSION}

This research is important because until now, within the realm of psychological counselling, it was only assumed that authenticity is the most fundamental aspect of mental health, without having an empirical confirmation of that relation (Wood et al., 2008).

The confirmation that authenticity is closely connected to mental health and significantly contributes to it is a good example of how classic perspectives in psychological counselling can set further directions of research within personality psychology.

\section{REFERENCES}

Barrett-Lennard, G. T. (1998). Carl Rogers' helping system: Journey and substance. London: Sage.

Deci, E. L. \& Ryan, R. M. (2008). Hedonia, eudaimonia, and well-being: An introduction. Journal of Happiness Studies, 9, 1-11.

Grégoire, S., Baron, L., Ménard, J., Lachance, L. (2014). The Authenticity Scale: Psychometric Properties of a French Translation and Exploration of Its Relationships with Personality and Well-Being. Canadian Journal of Behavioural Science, 46(3), 346-355. DOI: $10.1037 / \mathrm{a} 0030962$

Grijak, Dj. (2017). Psychometric evaluation of the Authenticity Scale on the sample of students in Serbia. Psihologija, 50(1), 85-99.

Harter, S., Marold, D. B., Whitesell, N. R., \& Cobbs, G. (1996). A model of the effects of parent and peer support on adolescent false self behavior. Child Development, 67, 360374. DOI: $10.2307 / 1131819$

Harter, S. (2002). Authenticity. In C. R. Snyder \& S. J. Lopez (Eds.), Handbook of positive psychology. Oxford, England: Oxford University Press.

Heubeck, B. G. \& Neill, J. T. (2000). Internal validity and reliability of the 30 item Mental Health Inventory for Australian Adolescents. Psychological Reports, 87, 431-440.

İlhan, T., Özdemir, Y (2013). Adaptation of Authenticity Scale to Turkish: A validity and Reliability Study. Turkish Psychological Counseling and Guidance Journal, 5(40), 142153.

Myers, D. G. \& Diener, E. (1995). Who is happy? Psychological Science, 6, 10-19.

Neff, K. D., \& Harter, S. (2002). The authenticity of conflict resolutions among adult couples: Does women's other-oriented behavior affect their true selves? Sex Roles, 47, 298-307.

Peterson, C. \& Seligman, M. E. P. (2004). Character strengths and virtues: A classification and handbook. New York: Oxford University Press/Washington, DC: American Psychological Association. 
Rogers, C. R. (1961). On becoming a person: A therapist's view of psychotherapy. London: Constable.

Ryan, R. M. \& Deci, E. L. (2001). On happiness and human potentials: A review of research on hedonic and eudaimonic well-being. Annual Review of Psychology, 52, 141-166.

Schmid, P. F. (2001). Authenticity: the person as his or her own author. Dialogical and ethical perspectives on therapy as an encounter relationship. And beyond . In Wyatt, G. (ed.), Congruence. Ross-on-Wye: PCCS.

Schmid, P.F. (2004). Authenticity and alienation. Person-Centered and Experiential Psychotherapies, 3, 36-51.

Seligman, M.E.P. (2002). Authentic Happiness: Using the New Positive Psychology to Realize Your Potential for Lasting Fulfilment. New York, NY: Free Press.

Shamsi, A., Ghamarani, A., Samadi, M., Ahmadzadeh, M. (2012). The Study Of The Validity And Reliability Of The Authentic Personality Scale. Journal Of Psychological Models and Methods, 2(8), 87-99.

Snyder, C. R. \& Lopez, S. J. (2009). Positive psychology. California: Sage Publications.

Veit, C. \& Ware, J. (1983). The structure of psychological distress and wellbeing in general populations. Journal of Consulting and Clinical Psychology, 51, 730-742.

Winefield, H.R., Gill, T.K., Taylor, A.W. \& Pilkington, R.M. (2012). Psychological wellbeing and psychological distress: Is it necessary to measure both? Theory, Research and Practice, 2, 1-14. http://dx.doi.org/10.1186/2211-1522-2-3

Wood, A.M., Linley, P.A., Maltby, J., Baliousis, M. \& Joseph, S. (2008). The authentic personality: A theoretical and empirical conceptualization and the development of the Authenticity Scale. Journal of Counselling Psychology 55(3), 385-399.

\title{
AUTENTIČNOST KAO PREDIKTOR MENTALNOG ZDRAVLJA
}

\begin{abstract}
Sažetak
Cilj ovog istraživanja bio je procijeniti odnos između autentičnosti i mentalnog zdravlja na uzorku od 706 studenata. Rezultati su pokazali da su sve subskale Skale autentičnosti (autentični život, prihvaćanje vanjskog utjecaja i samootuđenje) korelirane sa svim skalama i subskalama na MHI-38 (skala psihološki distres - subskale tjeskoba, depresija, gubitak kontrole ponašanja/emocionalne kontrole; skala psihička dobrobit - ukupni pozitivni afekt, emocionalne veze i zadovoljstvo životom; i ukupni indeks mentalnog zdravlja). Hijerarhijska regresijska analiza je pokazala da su svi čimbenici autentičnosti zajedno statistički značajni prediktori psihološkog distresa, psihičke dobrobiti i ukupnog mentalnog zdravlja indeksa. Potvrda da je autentičnost povezana s mentalnim zdravljem i da mu značajno doprinosi dobar je primjer kako klasične perspektive u psihološkom savjetovanju mogu postaviti daljnje smjernice istraživanja u okviru psihologije ličnosti.
\end{abstract}

Ključne riječi: autentičnost, mentalno zdravlje, studenti 